\title{
Interaction of Magnetic Nanoparticles in Cells of Human Breast Adenocarcinoma (MCF-7)
}

Karina Midori Endo ${ }^{1 *}$, Raquel Dosciatti Bini2 ${ }^{*}$, Danielle Lazarin-Bidóia ${ }^{3}$, Veronica Elisa Pimenta Vicentini ${ }^{1}$ and Luiz Fernando Cótica ${ }^{2}$

1. Department of Biotechnology, Genetics and Cell Biology/State University of Maringa - UEM, Maringa, Brazil.

2. Department of Physics/State University of Maringa - UEM, Maringa, Brazil.

3. Department of Pharmaceutical Sciences/State University of Maringa - UEM, Maringa, Brazil.

* Corresponding author: karinaendo@gmail.com

Nanotechnology is a field of interdisciplinary and multidisciplinary research with numerous potential applications and scientific advances in the treatment of cancer [1] [2]. In the search for alternatives to improve efficiency and minimize the effects of non-invasive treatments, magnetic nanoparticles (MNPs) are the most promising candidates due to their superparamagnetic behavior, biocompatibility and easy synthesis [3]. Thus, the objective of this study was to evaluate the cytotoxic activity, using the MTT assay, and analyze possible morphological changes by SEM in breast cancer cells (MCF-7), exposed to the MNPs $\left(\mathrm{Fe}_{3} \mathrm{O}_{4}\right)$ and MNPs coated with chitosan $\left(\mathrm{CS}-\mathrm{Fe}_{3} \mathrm{O}_{4}\right)$. For the MTT assay, the cells were treated with different concentrations of $\mathrm{Fe}_{3} \mathrm{O}_{4}$ and $\mathrm{CS}-\mathrm{Fe}_{3} \mathrm{O}_{4}$ for 24 and 48 hours. For the SEM, cells treated and incubated for $48 \mathrm{~h}$ with $\mathrm{Fe}_{3} \mathrm{O}_{4}$ and $\mathrm{CS}-\mathrm{Fe}_{3} \mathrm{O}_{4}$ were fixed, dehydrated, critical point-dried in $\mathrm{CO}_{2}$, sputtercoated with gold and observed using FEI Scios. Analysis by TEM showed that the MNPs have a spherical shape and the $\mathrm{CS}-\mathrm{Fe}_{3} \mathrm{O}_{4}$ are more dispersed and less agglomerated in relation to $\mathrm{Fe}_{3} \mathrm{O}_{4}$. It was observed in the MTT assay that $\mathrm{Fe}_{3} \mathrm{O}_{4}$ and $\mathrm{CS}-\mathrm{Fe}_{3} \mathrm{O}_{4}$ were not statistically cytotoxic in MCF-7 for all concentrations and incubation periods. MCF-7 treated with $\mathrm{Fe}_{3} \mathrm{O}_{4}$ and $\mathrm{CS}-\mathrm{Fe}_{3} \mathrm{O}_{4}$ and visualized by $\mathrm{SEM}$ showed that both MNPs showed similar morphology to control, presenting cells of polygonal shape, well adhered to the substrate and covered with numerous microvilli and not seem to have been changed by the treatment with the MNPs. In this way, in biomedical applications, the $\mathrm{CS}-\mathrm{Fe}_{3} \mathrm{O}_{4}$ can open new possibilities in use as carriers of drugs. 


\section{References:}

[1] E M Ali et al., Int J Biol Macromol. 120 (2018), p. 1170.

[2] F Assa et al., Crit Rev Biotechnol. 37 (2017), p. 492.

[3] S Lotfi et al., J Supercond Nov Magn. 30 (2017), p. 3031.

[4] This research was supported by CNPq (Brazil).

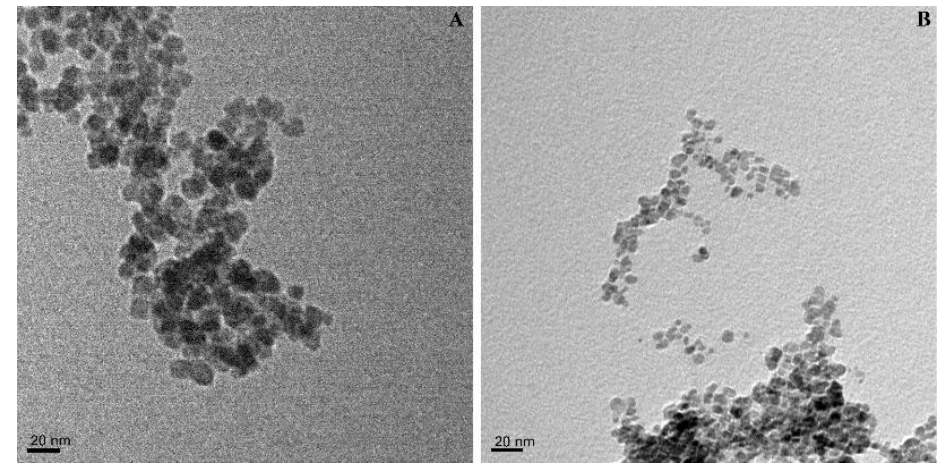

Figure 1. Transmission electron microscopy for magnetic nanoparticles (A) $\mathrm{Fe}_{3} \mathrm{O}_{4}$ and (B) $\mathrm{CS}-\mathrm{Fe}_{3} \mathrm{O}_{4}$.

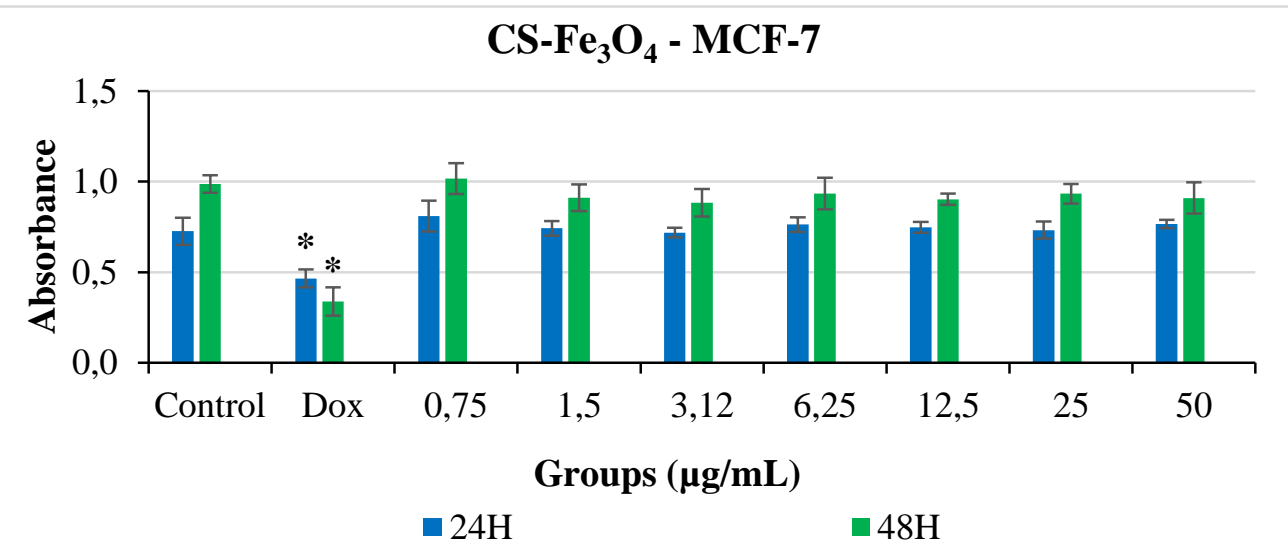

Figure 2. Mean and standard deviation obtained by the MTT test. Groups: Control (DMEM + 10\% FBS), and different concentrations of $\mathrm{CS}_{-}-\mathrm{Fe}_{3} \mathrm{O}_{4}(0.75,1.5,3.12,6.25,12.5,25$ and $50 \mu \mathrm{g} / \mathrm{mL})$ were incubated with MCF-7 cells for 24 and 48 hours. *Statistically significant difference in relation to control $(\mathrm{p}<0.05)$.

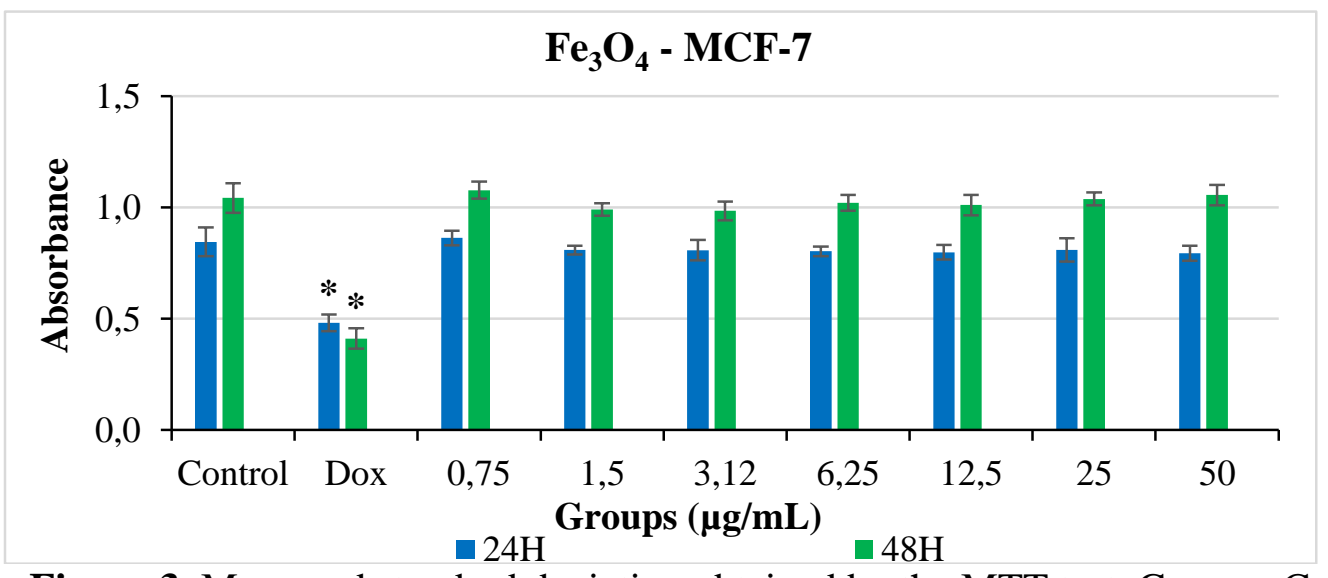

Figure 3. Mean and standard deviation obtained by the MTT test. Groups: Control (DMEM + 10\% FBS), and different concentrations of $\mathrm{Fe}_{3} \mathrm{O}_{4}(0.75,1.5,3.12,6.25,12.5,25$ and $50 \mu \mathrm{g} / \mathrm{mL})$ were incubated with MCF-7 cells for 24 and 48 hours. *Statistically significant difference in relation to control $(\mathrm{p}<0.05)$. 


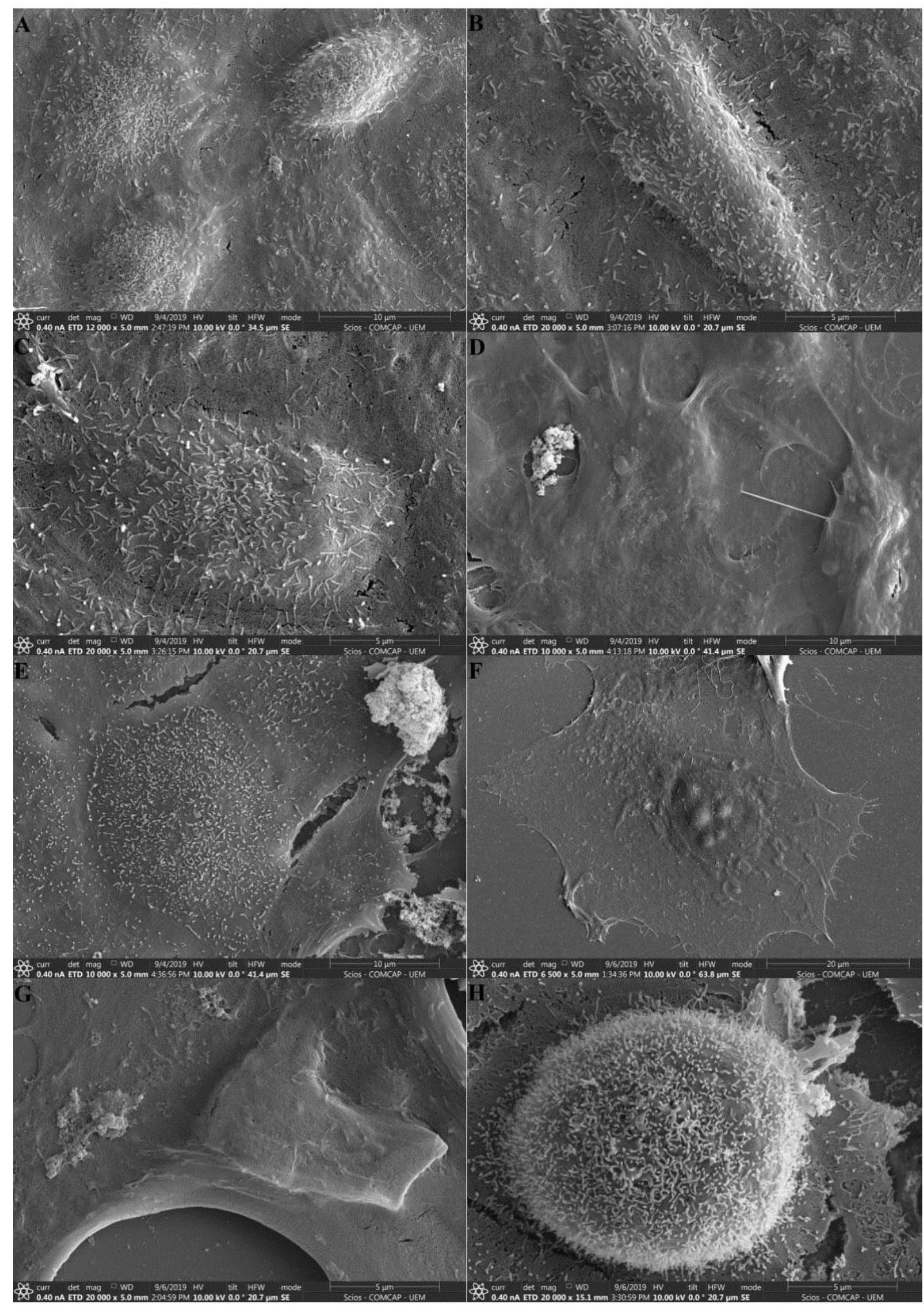

Figure 4. Scanning electron microscopy (SEM) images of MCF-7 cells, incubated with different magnetic nanoparticle treatments for 48 hours. (A, B) Control (C) $\mathrm{Fe}_{3} \mathrm{O}_{4} 6.25 \mu \mathrm{g} / \mathrm{mL}$; (D) $\mathrm{Fe}_{3} \mathrm{O}_{4} 25 \mu \mathrm{g} / \mathrm{mL}$; (E) $\mathrm{Fe}_{3} \mathrm{O}_{4}$ $50 \mu \mathrm{g} / \mathrm{mL}$; (F) CS-Fe $\mathrm{O}_{4} 6.25 \mu \mathrm{g} / \mathrm{mL}$; (G) CS-Fe $\mathrm{O}_{4} 25 \mu \mathrm{g} / \mathrm{mL}$; (H) CS-Fe ${ }_{3} \mathrm{O}_{4} 50 \mu \mathrm{g} / \mathrm{mL}$. 